\title{
Comparison of Cell Proliferation, Protein, and Glucose Metabolism in Musculoskeletal Tumors in a PET Study
}

\author{
Mei Tian, ${ }^{1,2,3}$ Hong Zhang, 1, 2, 4, 5,6 and Keigo Endo ${ }^{2}$ \\ ${ }^{1}$ Department of Nuclear Medicine, Second Affiliated Hospital of Zhejiang University School of Medicine, Hangzhou, \\ Zhejiang 310009, China \\ ${ }^{2}$ Department of Nuclear Medicine and Diagnostic Radiology, Gunma University School of Medicine, Maebashi, \\ Gunma 371-8511, Japan \\ ${ }^{3}$ The University of Texas MD Anderson Cancer Center, Houston, TX 77030, USA \\ ${ }^{4}$ Zhejiang University Medical PET Center, Hangzhou, Zhejiang 310058, China \\ ${ }^{5}$ The Institute of Nuclear Medicine and Molecular Imaging of Zhejiang University, Hangzhou, Zhejiang 310009, China \\ ${ }^{6}$ Key Laboratory of Medical Molecular Imaging of Zhejiang Province, Hangzhou, Zhejiang 310009, China
}

Correspondence should be addressed to Hong Zhang, hzhang21@gmail.com

Received 29 December 2010; Revised 19 March 2011; Accepted 25 March 2011

Academic Editor: Zhen Cheng

Copyright () 2011 Mei Tian et al. This is an open access article distributed under the Creative Commons Attribution License, which permits unrestricted use, distribution, and reproduction in any medium, provided the original work is properly cited.

${ }^{11} \mathrm{C}$-choline and ${ }^{18} \mathrm{~F}$-FAMT are known to correlate with tumor cell proliferation and amino acid metabolism. We investigated the ability of ${ }^{11} \mathrm{C}$-Choline and ${ }^{18} \mathrm{~F}$-FAMT PET in diagnosis of musculoskeletal tumors in thirty-six patients in comparison of ${ }^{18} \mathrm{~F}-\mathrm{FDG}$ PET. ${ }^{11} \mathrm{C}$-Choline and ${ }^{18} \mathrm{~F}$-FDG PET were positive in all the malignant tumors $(n=13)$, whereas ${ }^{18} \mathrm{~F}$-FAMT was positive in 11 tumors. The mean SUVs for malignant tumors were significantly higher than those for benign lesions in all three tracers imaging. A moderate correlation was found between ${ }^{11} \mathrm{C}$-Choline and ${ }^{18} \mathrm{~F}-\mathrm{FDG}(r=0.540, P<.05)$, or ${ }^{18} \mathrm{~F}-\mathrm{FAMT}$ and FDG $(r=0.596$, $P<.05)$. The diagnostic sensitivity and specificity for malignancy were $91.7 \%$ and $71.4 \%$, respectively, using ${ }^{11} \mathrm{C}$-choline with a SUV cut-off of 2.69 . The sensitivity and specificity of ${ }^{18}$ F-FAMT for malignancy were $66.7 \%$ and $85.7 \%$, respectively, using a SUV cut-off of 1.26 . For ${ }^{18} \mathrm{~F}-\mathrm{FDG}$, using a SUV cut-off of 2.77 , the sensitivity and specificity were $83.3 \%$ and $71.4 \%$, respectively. According to ROC analysis, the ROC curves for ${ }^{11} \mathrm{C}$-Choline, ${ }^{18} \mathrm{~F}$-FAMT, and ${ }^{18} \mathrm{~F}$-FDG were $0.855,0.734$, and 0.847 , respectively. ${ }^{11} \mathrm{C}$-Choline PET is superior in the visualization of musculoskeletal tumors with high contrast imaging, whereas the combination of ${ }^{18} \mathrm{~F}$-FAMT and ${ }^{18} \mathrm{~F}$-FDG PET provides valuable information for the preoperative planning in patients with musculoskeletal tumors.

\section{Introduction}

Musculoskeletal tumors generally present clinically as large masses that are often heterogeneous and have different biological behaviors. The diagnosis and treatment of such lesions is often complex [1]. Generally, the anatomical imaging methods, such as conventional radiology, CT, and MRI, are very important for the assessment of tumor location, form, size, infiltration, and extent. However, the radiographic appearance of many tumors is indeterminate, especially CT and MRI have limited ability to allow distinction of malignant from benign lesions and final diagnosis may only be achieved using biopsy and histopathologic evaluation. Furthermore, in case of large-size tumors, the highest-grade part of the lesion may be missed on a biopsy of only a small region [2]. This results in errors in the diagnosis and grading of the tumor and thus suboptimal management of the disease. An imaging technique that enables reliable distinction of malignant from benign musculoskeletal lesions would thus be of considerable clinical value.

During the last decade, positron emission tomography (PET) has become an essential tool in the management of a growing number of cancer patients [3-5]. 2- $\left[{ }^{18} \mathrm{~F}\right]$ fluoro2-deoxy-D-glucose ( $\left.{ }^{18} \mathrm{~F}-\mathrm{FDG}\right)$ is by far the most common radiopharmaceutical for PET in clinical use and has shown a high sensitivity for diagnosing and staging a wide variety of malignant diseases. However, there are several limitations for the use of ${ }^{18} \mathrm{~F}-\mathrm{FDG}$ in discriminating benign lesions from soft 
tissue sarcomas [6]. Glucose metabolism is not significantly increased in some bone tumor types [7]. The most significant drawback of ${ }^{18} \mathrm{~F}$-FDG for oncologic purpose results from the absence of specificity for musculoskeletal tumor [8]. Infection, inflammation, granulomatous diseases, and many other physiologic or pathologic conditions can also show high ${ }^{18} \mathrm{~F}-\mathrm{FDG}$ uptake. To overcome these limitations, new PET imaging agents and its applications are required.

So far, only few PET imaging agents have been developed and used for the detection of musculoskeletal tumors. One potential imaging agent is radiolabeled amino acid, which can be used as the marker of cell proliferation and microvessel density of the tumors [3,9]. Various studies have demonstrated that increased uptake of amino acid compound is predominantly due to a higher L-amino acid transporter (LAT) activity. Transport of the amino acid into the cell can be followed by rapid metabolization and trapping inside the cell, for example, as in the case for L-3- $\left[{ }^{18} \mathrm{~F}\right]-6$ $\alpha$-methyltyrosine $\left({ }^{18} \mathrm{~F}-\mathrm{FAMT}\right)$. Although the exact trapping mechanism is not known, this selective uptake pattern results in a very high tumor-to-background (T/B) ratio enabling clear delineation of the tumor [10-12].

Another attractive imaging agent is $\left[\right.$ methyl $\left.-{ }^{11} \mathrm{C}\right]$ choline $\left({ }^{11} \mathrm{C}\right.$-choline), which has been increasingly used for the evaluation of various cancers [4]. Choline is quaternary amine that is ubiquitously distributed in cells, mostly in the form of phospholipids. In vivo and in vitro studies have shown that the increased ${ }^{11} \mathrm{C}$-choline uptake in the tumor cells is proportional to the rate of tumor duplication [13-15]. ${ }^{11} \mathrm{C}$-choline PET imaging shows that liver and kidney are the major sites for choline oxidation or excretion; negligible activity is present in the bone and soft tissues, which indicates its noteworthy advantage for the detection of musculoskeletal tumors.

Since the differences in uptake mechanism are present, it will be interesting to find out the correlations and differences in the patterns of PET imaging of ${ }^{18} \mathrm{~F}-\mathrm{FDG},{ }^{18} \mathrm{~F}$-FAMT and ${ }^{11} \mathrm{C}$-choline, especially during the same time period within the same setting. However, until now, there has as yet only limited experience of use of ${ }^{18} \mathrm{~F}$-FAMT and ${ }^{11} \mathrm{C}$-choline PET in patients with musculoskeletal tumors $[4,16]$. The aim of this study was to compare the characteristics of ${ }^{18} \mathrm{~F}$ FDG, ${ }^{18} \mathrm{~F}$-FAMT, and ${ }^{11} \mathrm{C}$-choline PET for the detection of musculoskeletal tumors in the same patient population.

\section{Materials and Methods}

2.1. Patients. Thirty-six consecutive patients ( 14 female and 22 male; age range: 11 to 84 years) with or suspected of having malignancies in the musculoskeletal system were enrolled in this prospective study. All the patients underwent ${ }^{18} \mathrm{~F}$-FDG PET, ${ }^{18}$ F-FAMT, ${ }^{11} \mathrm{C}$-choline, and computed tomography (CT) or magnetic resonance imaging (MRI) in a random order within a maximum interval of 2 weeks. No therapeutic medication has been changed during this period, and none of the patients had diabetes mellitus. The blood glucose level during the PET study was ranged from 64 to $95 \mathrm{mg} / \mathrm{dL}$ (3.5$5.3 \mathrm{mmol} / \mathrm{L}$ ). Patients had surgical operation or biopsy after the completion of the above imaging examinations based on the information of tumor PET imaging and CT and MRI images, and the resected tumor specimens were submitted for the pathological diagnosis. The imaging protocols of ${ }^{18} \mathrm{~F}-$ FDG PET, ${ }^{18} \mathrm{~F}$-FAMT, and ${ }^{11} \mathrm{C}$-choline were approved by the Institutional Review Board of the Institute of Gunma University. Informed consents of this study were obtained from all patients.

2.2. PET Imaging. PET imaging agents of ${ }^{18} \mathrm{~F}-\mathrm{FDG},{ }^{18} \mathrm{~F}-$ FAMT, and ${ }^{11} \mathrm{C}$-choline were prepared using a cyclotron and automated synthetic apparatuses that were reported by Hamacher et al. [17], Tomiyoshi et al. [10], and Hara and Yuasa [13], respectively. PET scans were performed with a SET-2400 W (Shimadzu Corporation, Kyoto, JAPAN), which had a large $20 \mathrm{~cm}$ axial field of view and $59.5 \mathrm{~cm}$ transaxial field of view, giving 63 two-dimensional imaging planes. The transaxial spatial resolution was $4.2 \mathrm{~mm}$ full width at half maximum (FWHM) at the center of the field of view, and the axial resolution was $5.0 \mathrm{~mm}$ FWHM. Each patient had an overnight fasting before ${ }^{18} \mathrm{~F}-\mathrm{FDG},{ }^{18} \mathrm{~F}$-FAMT, and ${ }^{11} \mathrm{C}$-choline PET. ${ }^{18} \mathrm{~F}$-FDG and ${ }^{18} \mathrm{~F}$-FAMT PET were started $40 \mathrm{~min}$ after the administration of approximately $320 \mathrm{MBq}$ ${ }^{18} \mathrm{~F}-\mathrm{FDG}$ and $260 \mathrm{MBq}{ }^{18} \mathrm{~F}$-FAMT, and static image data was acquired for $8 \mathrm{~min}$ per bed position, respectively. ${ }^{11} \mathrm{C}$ choline PET was performed $5 \mathrm{~min}$ after the intravenous injection of approximately $370 \mathrm{MBq}{ }^{11} \mathrm{C}$-choline, and static image data was acquired for $5 \mathrm{~min}$ per bed position. PET data was acquired by simultaneous transmission-emission method [18]. Images were reconstructed by the order subsets expectation maximization (OSEM) algorithm into a $128 \times$ 128 matrix with pixel dimensions of $4.0 \mathrm{~mm}$ in plane and $3.125 \mathrm{~mm}$ axially. The image with $9.4 \mathrm{~mm}$ thickness was generated for interpretation and semiquantitative analysis.

2.3. Image Analysis. PET images were separately interpreted by two nuclear medicine physicians until consensus was reached. Clinical information and conventional images such as radiographys, CT scans, and MRI images were available at the time of image interpretation. The ${ }^{18} \mathrm{~F}-\mathrm{FDG},{ }^{18} \mathrm{~F}$-FAMT, and ${ }^{11} \mathrm{C}$-choline uptakes were evaluated by both qualitative and semiquantitative methods. The qualitative analysis was performed by the visual evaluation of tumor tracer uptake. Tumor lesions were identified as areas of focally increased uptake, exceeding that of surrounding tissues or organs. The degree of tracer uptake was visually classified as negative (-) and positive $(+$ or ++$)$ results. The semiquantitative analysis was performed using the standardized uptake value (SUV). The regions of interest (ROI) in $1 \mathrm{~cm}$ diameter were drawn on the lesions including the highest activity. SUV was then determined as the average of the radioactivity in the tumors divided by the injected radioactivity normalized to the body weight. The mean value per pixel in the ROI for assessing SUV was employed for semiquantitative analysis. All PET findings were finally compared with CT and/or MRI images, and the results of pathological diagnosis.

2.4. Statistical Analysis. Data were expressed as mean \pm SD or total number (\%). A linear regression analysis was 
TABle 1: Patient characteristics and results of PET studies.

\begin{tabular}{|c|c|c|c|c|c|c|c|c|c|c|c|c|}
\hline \multirow{2}{*}{ Patient no. } & \multirow{2}{*}{ Age } & \multirow{2}{*}{ Sex } & \multirow{2}{*}{$\begin{array}{l}\text { Histological } \\
\text { diagnosis }\end{array}$} & \multirow{2}{*}{ Grade } & \multirow{2}{*}{ Location } & \multirow{2}{*}{$\begin{array}{c}\text { Lesion } \\
\text { size }(\mathrm{mm})\end{array}$} & \multicolumn{2}{|c|}{ Choline } & \multicolumn{2}{|c|}{ FAMT } & \multicolumn{2}{|c|}{ FDG } \\
\hline & & & & & & & Visual & SUV & Visual & SUV & Visual & SUV \\
\hline \multicolumn{13}{|l|}{ Benign } \\
\hline 1 & 44 & $\mathrm{~F}$ & Xanthofibroma & - & Tibia & $40 \times 40 \times 40$ & ++ & 4.90 & ++ & 1.10 & ++ & 3.30 \\
\hline 2 & 51 & $\mathrm{~F}$ & Enchondroma & - & Scapular & $27 \times 30 \times 60$ & + & 0.75 & + & 0.72 & + & 0.70 \\
\hline 3 & 50 & M & $\begin{array}{l}\text { No definite } \\
\text { residual tumor } \\
\text { cells }\end{array}$ & - & Knee & $50 \times 50 \times 50$ & ++ & 0.98 & ++ & 1.24 & ++ & 1.74 \\
\hline 4 & 58 & M & Schwannoma & - & Thigh & $35 \times 35 \times 35$ & ++ & 1.80 & + & 0.71 & ++ & 1.70 \\
\hline 5 & 59 & $\mathrm{~F}$ & $\begin{array}{l}\text { Bursitis with } \\
\text { synovitis }\end{array}$ & - & Knee & $20 \times 20 \times 20$ & ++ & 1.13 & - & - & + & 0.60 \\
\hline 6 & 15 & $\mathrm{~F}$ & $\begin{array}{l}\text { Eosinophilic } \\
\text { granuloma }\end{array}$ & - & Eosinophilic & $30 \times 30 \times 55$ & ++ & 2.20 & ++ & 0.90 & ++ & 2.69 \\
\hline 7 & 57 & M & Fibroma & - & Scapula & $30 \times 30 \times 50$ & + & 0.62 & ++ & 1.70 & ++ & 1.53 \\
\hline 8 & 62 & $\mathrm{~F}$ & Schwannoma & - & Carpal & $5 \times 9 \times 10$ & ++ & 1.50 & ++ & 0.91 & ++ & 1.80 \\
\hline 9 & 60 & M & Neurofibroma & - & Femur & $50 \times 60 \times 150$ & ++ & 5.10 & ++ & 1.40 & ++ & 3.49 \\
\hline 10 & 53 & M & Giant cell tumor & - & Knee & $35 \times 35 \times 35$ & ++ & 4.20 & + & 0.65 & ++ & 4.36 \\
\hline 11 & 53 & M & $\begin{array}{l}\text { Degeneration of } \\
\text { skeletal muscle }\end{array}$ & - & Lower leg & $27 \times 30 \times 60$ & ++ & 0.90 & + & 0.74 & + & 0.60 \\
\hline 12 & 26 & $\mathrm{~F}$ & Giant cell tumor & - & Femur & $28 \times 31 \times 42$ & ++ & 8.00 & ++ & 1.10 & ++ & 8.39 \\
\hline 13 & 15 & $\mathrm{~F}$ & Desmoid tumor & - & Lower leg & $40 \times 60 \times 70$ & ++ & 3.30 & + & 0.76 & ++ & 2.20 \\
\hline 14 & 27 & $\mathrm{~F}$ & Giant cell tumor & - & Knee & $30 \times 30 \times 40$ & ++ & 1.12 & + & 0.71 & ++ & 3.23 \\
\hline 15 & 48 & M & Desmoid tumor & - & Carpal & $30 \times 40 \times 60$ & ++ & 3.10 & ++ & 1.00 & ++ & 2.77 \\
\hline 16 & 61 & M & Desmoid tumor & - & Back & $40 \times 40 \times 70$ & ++ & 2.30 & ++ & 1.17 & ++ & 2.14 \\
\hline 17 & 55 & M & Lymphangioma & - & Knee & $30 \times 40 \times 50$ & ++ & 1.69 & ++ & 0.92 & ++ & 1.37 \\
\hline 18 & 51 & M & Lymphangioma & - & Axilla & $30 \times 40 \times 50$ & ++ & 1.70 & ++ & 1.26 & ++ & 2.10 \\
\hline 19 & 31 & M & Schwannoma & - & Lower leg & $10 \times 20 \times 30$ & ++ & 0.88 & + & 0.56 & ++ & 0.81 \\
\hline 20 & 47 & M & Desmoid tumor & - & Thigh & $65 \times 46 \times 68$ & ++ & 2.46 & ++ & 1.64 & ++ & 3.27 \\
\hline 21 & 58 & M & Aseptic necrosis & - & Talus & $30 \times 30 \times 30$ & ++ & 2.40 & ++ & 1.20 & ++ & 1.74 \\
\hline 22 & 20 & M & $\begin{array}{l}\text { Pigmented } \\
\text { villonodular } \\
\text { synovitis }\end{array}$ & - & Poples & $30 \times 30 \times 50$ & ++ & 2.69 & ++ & 0.86 & ++ & 2.60 \\
\hline 23 & 53 & $\mathrm{~F}$ & $\begin{array}{c}\text { Degenerative joint } \\
\text { disease }\end{array}$ & - & Femur & $40 \times 70 \times 110$ & ++ & 2.24 & + & 0.58 & ++ & 2.40 \\
\hline \multicolumn{13}{|l|}{ Malignant } \\
\hline 24 & 47 & M & Liposarcoma & 1 & Thigh & $70 \times 70 \times 120$ & ++ & 0.82 & - & - & + & 0.61 \\
\hline 25 & 43 & $\mathrm{~F}$ & Osteosarcoma & 2 & Tibia & $20 \times 24 \times 55$ & ++ & 9.30 & ++ & 2.00 & ++ & 6.00 \\
\hline 26 & 53 & $\mathrm{~F}$ & $\begin{array}{l}\text { Malignant } \\
\text { lymphoma }\end{array}$ & 3 & Clavicle & $27 \times 28 \times 30$ & ++ & 4.50 & ++ & 0.91 & ++ & 4.90 \\
\hline 27 & 17 & M & Ewing's sarcoma & 3 & Femur & $54 \times 50 \times 150$ & ++ & 2.60 & + & 0.58 & ++ & 0.89 \\
\hline 28 & 54 & $\mathrm{~F}$ & $\begin{array}{l}\text { Metastatic } \\
\text { carcinoma }\end{array}$ & 3 & Carpal & $50 \times 50 \times 60$ & ++ & 9.00 & ++ & 1.06 & ++ & 3.19 \\
\hline 29 & 83 & $\mathrm{~F}$ & $\begin{array}{l}\text { Malignant } \\
\text { lymphoma }\end{array}$ & 3 & Femur & $50 \times 80 \times 196$ & ++ & 7.30 & ++ & 7.00 & ++ & 14.49 \\
\hline 30 & 12 & M & Osteosarcoma & 3 & Femur & $50 \times 50 \times 60$ & ++ & 6.40 & ++ & 2.62 & ++ & 3.15 \\
\hline 31 & 14 & $\mathrm{~F}$ & Osteosarcoma & 3 & Femur & $60 \times 70 \times 160$ & ++ & 4.12 & ++ & 1.27 & ++ & 13.66 \\
\hline 32 & 11 & M & Osteosarcoma & 3 & Femur & $60 \times 70 \times 170$ & ++ & 3.68 & ++ & 2.12 & ++ & 4.90 \\
\hline 33 & 12 & M & Osteosarcoma & 3 & Femur & $50 \times 100 \times 140$ & ++ & 3.03 & ++ & 1.38 & ++ & 5.37 \\
\hline
\end{tabular}


TABle 1: Continued.

\begin{tabular}{|c|c|c|c|c|c|c|c|c|c|c|c|c|}
\hline \multirow{2}{*}{ Patient no. } & \multirow{2}{*}{ Age } & \multirow{2}{*}{ Sex } & \multirow{2}{*}{$\begin{array}{l}\text { Histological } \\
\text { diagnosis }\end{array}$} & \multirow{2}{*}{ Grade } & \multirow{2}{*}{ Location } & \multirow{2}{*}{$\begin{array}{c}\text { Lesion } \\
\text { size }(\mathrm{mm})\end{array}$} & \multicolumn{2}{|c|}{ Choline } & \multicolumn{2}{|c|}{ FAMT } & \multicolumn{2}{|c|}{ FDG } \\
\hline & & & & & & & Visual & SUV & Visual & SUV & Visual & SUV \\
\hline 34 & 64 & M & Myeloma & 3 & Sacrum & $40 \times 51 \times 60$ & ++ & 3.60 & ++ & 1.80 & ++ & 2.55 \\
\hline 35 & 84 & M & Liposarcoma & 3 & Femur & $230 \times 280 \times 360$ & ++ & 3.20 & - & 0.30 & ++ & 6.00 \\
\hline 36 & 44 & M & $\begin{array}{l}\text { Metastatic } \\
\text { carcinoma }\end{array}$ & 3 & Femur & $11 \times 22 \times 40$ & ++ & 5.10 & ++ & 1.90 & ++ & 1.90 \\
\hline
\end{tabular}

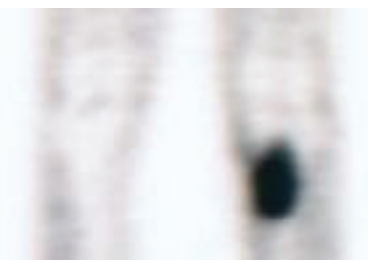

(a)

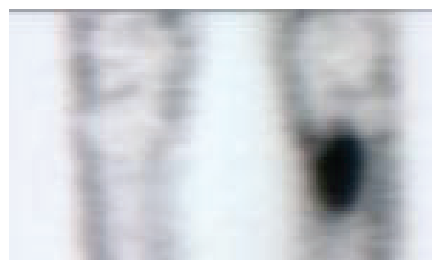

(b)

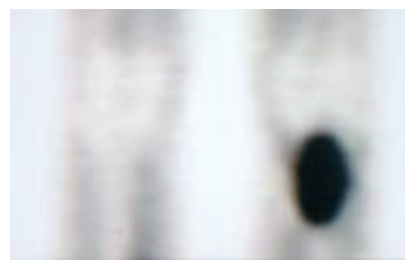

(c)

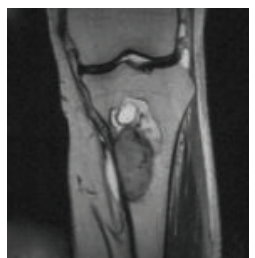

(d)

Figure 1: A 43-year-old female with osteosarcoma. ${ }^{18} \mathrm{~F}-\mathrm{FDG}(\mathrm{SUV}=6.0)(\mathrm{a}),{ }^{18} \mathrm{~F}$-FAMT $(\mathrm{SUV}=2.0)(\mathrm{b})$, and ${ }^{11} \mathrm{C}$-choline $(\mathrm{SUV}=9.3)(\mathrm{c})$ demonstrated high tracer uptake in the tumor of the left tibia, which corresponded to the area that was enhanced on MRI image (d).

TABLE 2: Results of the ROC analysis of FDG, FAMT, and choline PET in musculoskeletal tumors.

\begin{tabular}{lccccc}
\hline Tracer & AUC & $\begin{array}{c}\text { SUV } \\
\text { cutoff }\end{array}$ & $\begin{array}{c}\text { Sensitivity } \\
(\%)\end{array}$ & $\begin{array}{c}\text { Specificity } \\
(\%)\end{array}$ & $\begin{array}{c}\text { Accuracy } \\
(\%)\end{array}$ \\
\hline FDG & 0.847 & 2.77 & 83.3 & 71.4 & 69.7 \\
FAMT & 0.734 & 1.26 & 66.7 & 85.7 & 78.8 \\
Choline & 0.855 & 2.69 & 91.7 & 71.4 & 78.8 \\
\hline
\end{tabular}

AUC: area under the ROC curve.

performed for the correlation study. A multiple comparison test and $t$-test were used for the statistical analysis. A receiver operating characteristic (ROC) analysis was performed to compare the diagnostic abilities of ${ }^{18} \mathrm{~F}-\mathrm{FDG},{ }^{18} \mathrm{~F}-\mathrm{FAMT}$, and ${ }^{11} \mathrm{C}$-choline PET. A $P$ value $<.05$ was considered statistically significant.

\section{Results}

This study population included 36 patients with 36 musculoskeletal lesions. Patient clinical characteristics and imaging findings of ${ }^{11} \mathrm{C}$-choline, ${ }^{18} \mathrm{~F}$-FAMT, and ${ }^{18} \mathrm{~F}$-FDG PET were summarized in Table 1. Three typical cases are illustrated in Figures 1, 2, and 3.

3.1. Visual Analysis. In all 36 patients, 13 patients had malignant tumors and 23 had benign lesions, based on pathological findings of biopsy or surgical specimens. The diameter of the lesions ranged from $5 \times 9 \times 10 \mathrm{~mm}$ to $230 \times 280 \times 360 \mathrm{~mm}$ as determined by CT, MRI, or dissected surgical specimen. ${ }^{11} \mathrm{C}$-choline and ${ }^{18} \mathrm{~F}$-FDG PET was positive in all the 36 patients $(100 \%)$, whereas ${ }^{18}$ F-FAMT PET imaging were positive in 33 patients (84\%) and negative in 3 patients ( 1 bursitis with synovitis and 2 liposarcoma).
3.2. Semiquantitative Analysis. The mean $( \pm \mathrm{SD})$ SUVs for malignant tumors were significantly higher than those for benign lesions in all ${ }^{18} \mathrm{~F}-\mathrm{FDG},{ }^{18} \mathrm{~F}-\mathrm{FAMT}$, and ${ }^{11} \mathrm{C}$-choline PET analysis $(5.2 \pm 4.3, n=13$ versus $2.5 \pm 1.7, n=23$, $P<.002 ; 1.9 \pm 1.7, n=13$ versus $1.0 \pm 0.3, n=23, P<.02$; $4.8 \pm 2.5, n=13$ versus $2.4 \pm 1.8, n=23, P<.001$, resp.). The $P$ value showed a trend of significant relationship as ${ }^{11} \mathrm{C}$ choline $>{ }^{18} \mathrm{~F}-\mathrm{FDG}>{ }^{18} \mathrm{~F}-\mathrm{FAMT}$ for distinguishing malignant tumors from benign lesions.

As shown in Figure 4, the mean SUV of ${ }^{18}$ F-FDG and ${ }^{11} \mathrm{C}$-choline was significantly higher than that of ${ }^{18} \mathrm{~F}$-FAMT in either malignant tumors or benign tumors $(P<.002$, $P<.001$ and $P<.0001, P<.0002$, resp.), but there was no significant difference between ${ }^{18} \mathrm{~F}$-FDG and ${ }^{11} \mathrm{C}$-choline in either malignant tumors or benign tumors (n.s.).

The linear regression analysis was performed between ${ }^{11} \mathrm{C}$-choline and ${ }^{18} \mathrm{~F}$-FDG, as well as ${ }^{18} \mathrm{~F}$-FAMT and ${ }^{18} \mathrm{~F}$-FDG (Figure 5). Moderate correlations were noted between ${ }^{11} \mathrm{C}$ choline and ${ }^{18} \mathrm{~F}-\mathrm{FDG}$ in all lesions $(r=0.540, n=36)$ and ${ }^{18}$ F-FAMT and ${ }^{18}$ F-FDG $(r=0.596, n=36)$.

3.3. ROC Analysis. The results of ROC analysis using histopathological diagnosis as the gold standard were shown in Figure 6. The area under the curve (AUC) of ${ }^{18} \mathrm{~F}-\mathrm{FDG}$ PET, ${ }^{18} \mathrm{~F}-\mathrm{FAMT}$, and ${ }^{11} \mathrm{C}$-choline PET was $0.847,0.734$, and 0.855 , respectively. Table 2 summarized the sensitivity, specificity, and accuracy of ${ }^{18} \mathrm{~F}$-FDG, ${ }^{18} \mathrm{~F}$-FAMT, and ${ }^{11} \mathrm{C}$-choline PET. For example, in ${ }^{18} \mathrm{~F}$-FDG PET, the sensitivity, specificity, and accuracy were $83.3 \%, 71.4 \%$, and $69.7 \%$, respectively, when 2.77 of SUV was used as a cutoff. This would be $66.7 \%$, $85.7 \%$, and $78.8 \%$, respectively, for ${ }^{18} \mathrm{~F}$-FAMT as using a cutoff of SUV 1.26. ${ }^{11} \mathrm{C}$-choline PET was 91.9\%, 71.4\%, and $78.8 \%$, respectively, when 2.69 of SUV was used as a cutoff. The trend observed in the ROC analysis was that ${ }^{18} \mathrm{~F}$ FDG PET and ${ }^{11} \mathrm{C}$-choline PET had almost the same detect 


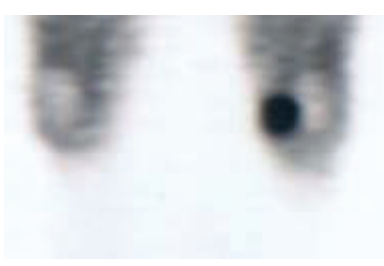

(a)

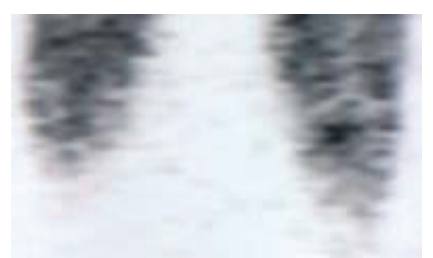

(b)

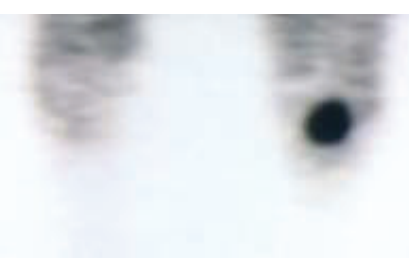

(c)

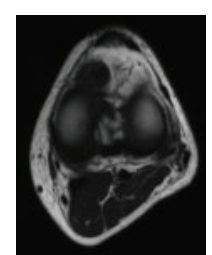

(d)

FIGURe 2: A 53-year-old male with giant cell tumor in the left knee. ${ }^{18} \mathrm{~F}-\mathrm{FDG}$ (SUV $\left.=4.36\right)(\mathrm{a})$ and ${ }^{11} \mathrm{C}$-choline $(\mathrm{SUV}=4.20)(\mathrm{c})$ demonstrated high tracer uptake in the tumor of the left knee, whereas ${ }^{18} \mathrm{~F}$-FAMT (SUV $=0.65$ ) (b) showed mild uptake, which corresponded to the area that was shown on MRI image (d).

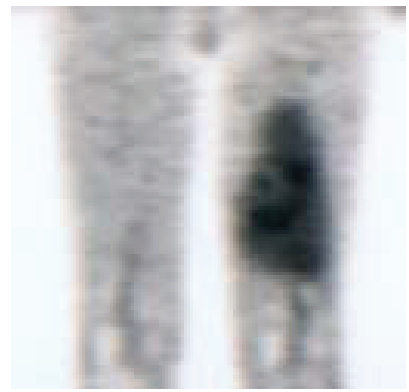

(a)

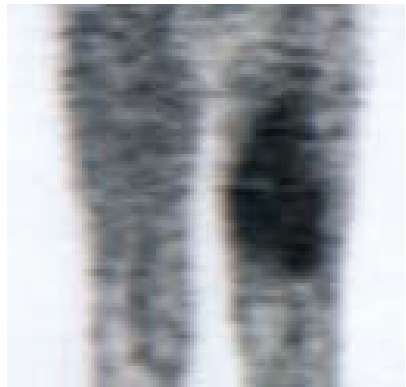

(b)

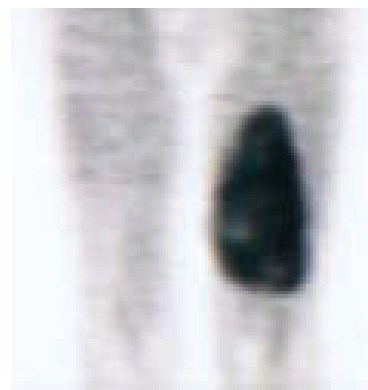

(c)

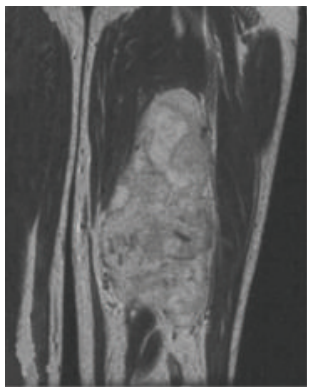

(d)

Figure 3: A 60-year-old male with neurofibroma in the left femur. ${ }^{18} \mathrm{~F}-\mathrm{FDG}$ (SUV = 3.49) (a), ${ }^{18} \mathrm{~F}-\mathrm{FAMT}(\mathrm{SUV}=1.40)(\mathrm{b})$, and ${ }^{11} \mathrm{C}$-choline $(\mathrm{SUV}=5.10)(\mathrm{c})$ showed clear tracer uptake in the tumor of the left femur, which corresponded to the area that was enhanced on MRI image (d).

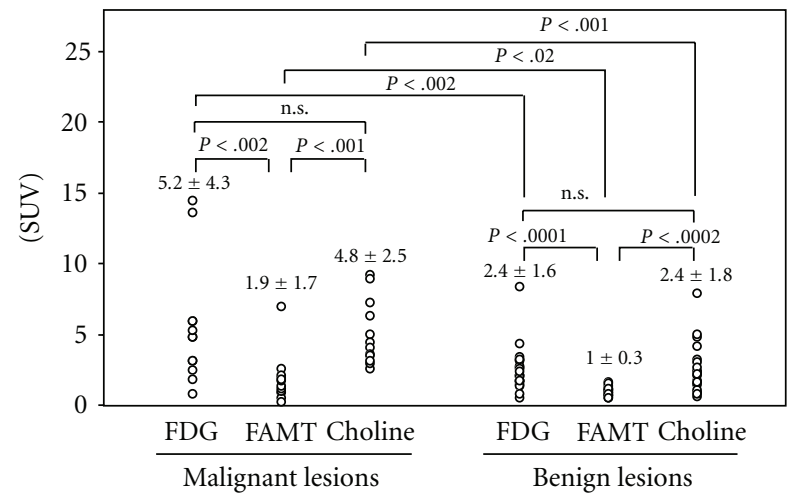

FIGURE 4: Standardized uptake value (SUV) of ${ }^{18} \mathrm{~F}-\mathrm{FDG},{ }^{18} \mathrm{~F}-\mathrm{FAMT}$, and ${ }^{11} \mathrm{C}$-choline in malignant and benign lesions. ${ }^{18} \mathrm{~F}$-FDG, ${ }^{18} \mathrm{~F}$ FAMT, and ${ }^{11} \mathrm{C}$-choline revealed significant higher SUV in malignant lesions than in benign lesions $(P<.002, P<.02$, and $P<$ .001 , resp.). Differences of tumor SUVs between ${ }^{18} \mathrm{~F}-\mathrm{FDG}$ and ${ }^{11} \mathrm{C}$ choline were not significant in both malignant and benign lesions, whereas both ${ }^{18} \mathrm{~F}-\mathrm{FDG}$ and ${ }^{11} \mathrm{C}$-choline SUVs were significantly higher than that of ${ }^{18} \mathrm{~F}$-FAMT.

ability in this patient population and showed better detection performance than that of ${ }^{18} \mathrm{~F}$-FAMT PET.

\section{Discussion}

The results of the present study indicate that ${ }^{11} \mathrm{C}$-choline and ${ }^{18} \mathrm{~F}$-FDG PET perform better than ${ }^{18} \mathrm{~F}$-FAMT in the detection of musculoskeletal tumors on the whole data analysis. However, in some benign lesions, such as bursitis or synovitis, ${ }^{18} \mathrm{~F}$-FAMT PET performed better than ${ }^{11} \mathrm{C}$ choline and ${ }^{18} \mathrm{~F}$-FDG PET in visualizing focal lesions. On the other hand, ${ }^{11} \mathrm{C}$-choline and ${ }^{18} \mathrm{~F}$-FAMT PET showed higher contrast compared with ${ }^{18} \mathrm{~F}-\mathrm{FDG}$ PET. Our findings were interpreted based on the pathological findings and analyzed to compare simultaneously the 3 PET imaging modalities.

Unsurprisingly, ${ }^{18} \mathrm{~F}$-FDG PET detected all the malignant tumors successfully; however, some benign lesions, such as benign giant cell tumor, desmoids tumor, and synovitis, also showed focal intensive uptakes. Although ${ }^{18}$ F-FDG PET has been widely used for the evaluation of various tumors, recent reports suggested that ${ }^{18} \mathrm{~F}-\mathrm{FDG}$ PET could not be used as a screening method for differential diagnosis between benign and malignant musculoskeletal lesions. A high accumulation of ${ }^{18}$ F-FDG can be observed in histiocytic, fibroblastic, and some neurogenic lesions, regardless of whether they are benign or malignant. More specific uses of ${ }^{18} \mathrm{~F}-\mathrm{FDG}$ PET, such as grading, staging, and monitoring of musculoskeletal sarcomas, should be considered for each tumor of a different histologic subtype [19].

The original application of ${ }^{11} \mathrm{C}$-choline was for detection of brain tumor and prostate cancer $[20,21] .{ }^{11} \mathrm{C}$-choline PET can give clearer images of brain tumors, whereas ${ }^{18} \mathrm{~F}-\mathrm{FDG}$ PET does not always delineate the border of the tumor. The high uptake of ${ }^{18} \mathrm{~F}$-FDG in the normal brain tissue frequently obscures the tumor uptake. Our present results showed that all the malignant tumors showed significant intensive accumulation in ${ }^{11} \mathrm{C}$-choline PET imaging. This was superior 


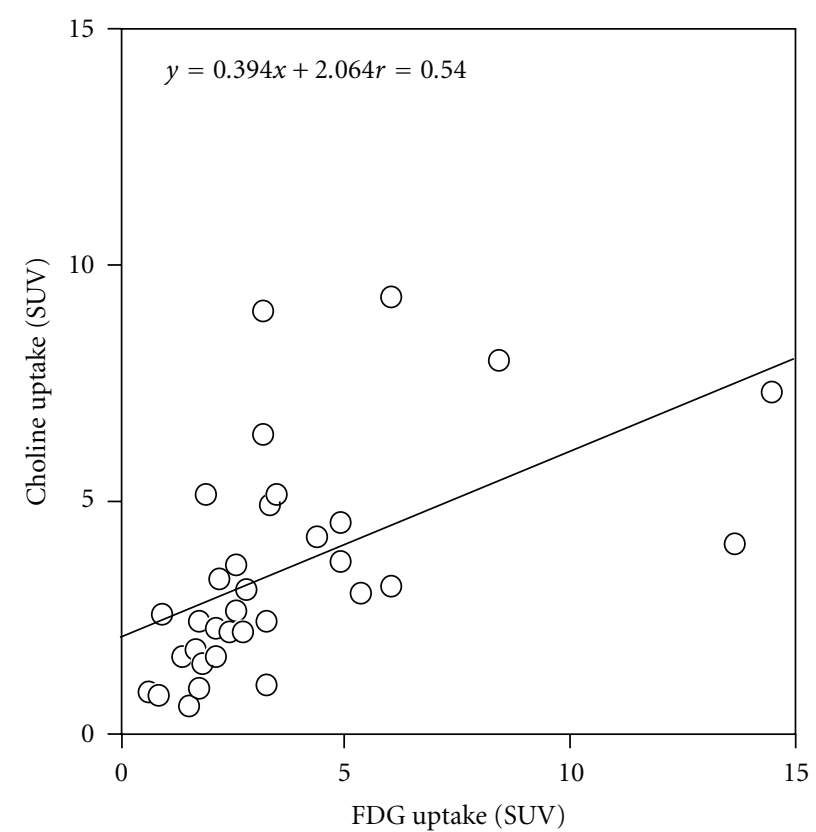

(a)

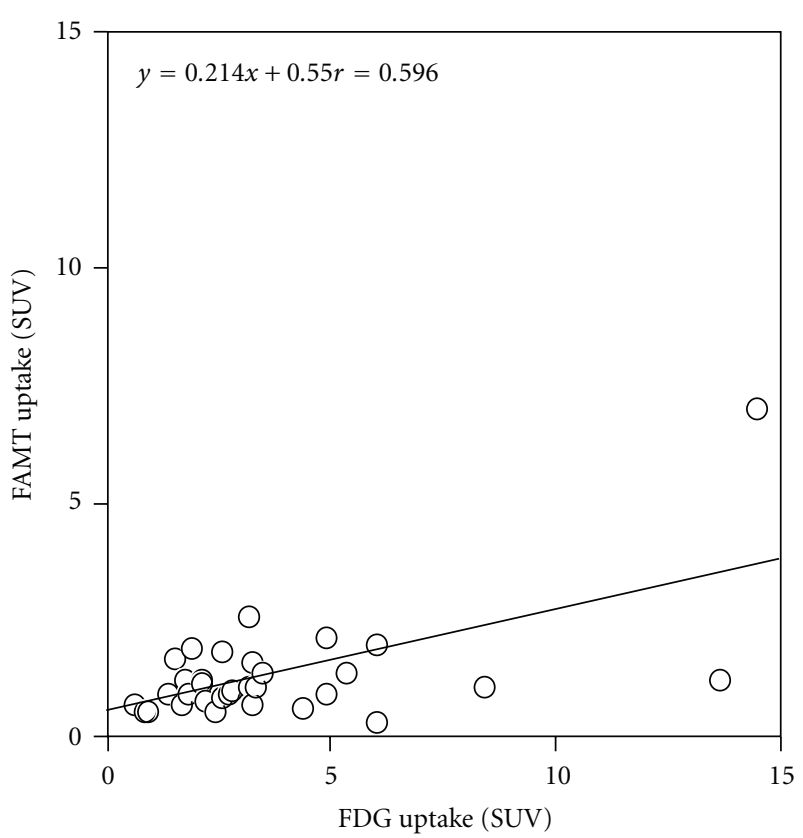

(b)

Figure 5: Relationship among ${ }^{18} \mathrm{~F}-\mathrm{FDG},{ }^{18} \mathrm{~F}-\mathrm{FAMT}$, and ${ }^{11} \mathrm{C}$-choline uptakes in musculoskeletal tumors. Moderate correlation was observed between ${ }^{11} \mathrm{C}$-choline uptake and ${ }^{18} \mathrm{~F}$-FDG uptake, and ${ }^{18} \mathrm{~F}$-FAMT and ${ }^{18} \mathrm{~F}$-FDG in all lesions.

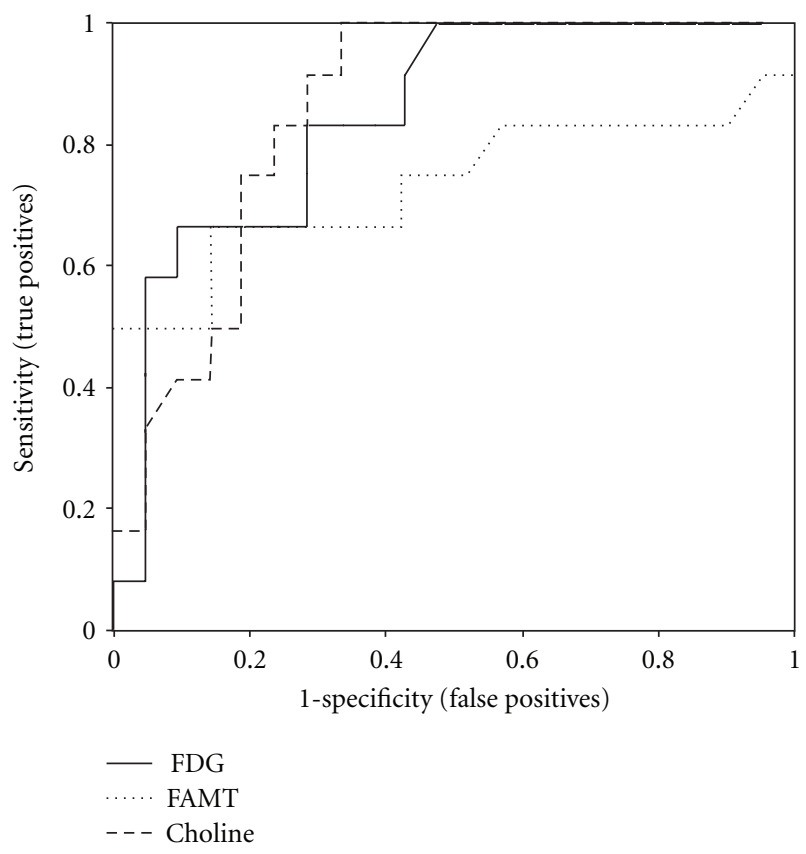

Figure 6: Comparison among ${ }^{18} \mathrm{~F}-\mathrm{FDG},{ }^{18} \mathrm{~F}-\mathrm{FAMT}$, and ${ }^{11} \mathrm{C}$-choline PET in differential diagnosis between malignant tumors and benign lesions by ROC analysis in musculoskeletal tumors.

to ${ }^{18} \mathrm{~F}$-FDG PET and ${ }^{18} \mathrm{~F}$-FAMT in differentiation between malignant and benign lesions. Thus, ${ }^{11} \mathrm{C}$-choline PET might be useful as a screening method for malignant bone and soft tissue tumors. The application of ${ }^{11} \mathrm{C}$-choline PET in evaluation of bone and soft tissue tumors is not yet well known.
Similarly, ${ }^{18}$ F-FAMT was also developed for the detection of brain tumors [22]. Watanabe et al. previously reported that ${ }^{18}$ F-FAMT may be superior to ${ }^{18} \mathrm{~F}$-FDG in the differentiation between benign and malignant tumors, while ${ }^{18} \mathrm{~F}-\mathrm{FDG}$ may be the better choice for noninvasive malignancy grading [16]. In the present patient population, the ${ }^{18}$ F-FAMT uptake was significantly higher in malignant tumors than in benign lesions, which partly supported the previous study.

To the best of our knowledge, this is the first study to compare the clinical utility of ${ }^{18} \mathrm{~F}-\mathrm{FDG},{ }^{18} \mathrm{~F}$-FAMT, and ${ }^{11} \mathrm{C}$ choline PET in detection of musculoskeletal tumors in a same patient population. We found that ${ }^{11} \mathrm{C}$-choline PET could detect and differentiate malignant musculoskeletal tumors with high sensitivity, as well as ${ }^{18}$ F-FDG PET, compared with ${ }^{18}$ F-FAMT PET. Based on visual evaluation, PET imaging clearly demonstrated intensive radioactive accumulation in $100 \%$ of the musculoskeletal tumors by using ${ }^{18} \mathrm{~F}$-FDG and ${ }^{11} \mathrm{C}$-choline, but only $84 \%$ if using ${ }^{18} \mathrm{~F}$ FAMT. The uptakes of all the 3 imaging agents, ${ }^{18} \mathrm{~F}-\mathrm{FDG}$, ${ }^{18} \mathrm{~F}$-FAMT, and ${ }^{11} \mathrm{C}$-choline, were significantly higher in malignant musculoskeletal tumors than those in benign lesions. ${ }^{11} \mathrm{C}$-choline and ${ }^{18} \mathrm{~F}-\mathrm{FDG}$ showed equal ability in detection of musculoskeletal tumors, followed by ${ }^{18} \mathrm{~F}$-FAMT.

A considerable overlap of SUVs was observed in the present study, due to a relatively large number of benign cases with various histological types included. It is noted that high ${ }^{11} \mathrm{C}$-choline uptake (SUV > 2.4) was found in 2 of 3 giant cell tumors, 3 of 4 desmoid tumors, 1 xanthofibroma, 1 neurofibroma, and 1 pigmented villonodular synovitis. Such false-positive cases were similar in ${ }^{18} \mathrm{~F}$-FDG PET. High FDG uptake ( $\mathrm{SUV}>2.4$ ) was noted in all 3 giant cell tumors, 2 of 4 desmoid tumors, 1 xanthofibroma, 1 neurofibroma, 
1 eosinophilic granuloma, and 1 pigmented villonodular synovitis. Most of the false-positive cases in this study could be classified as histiocytic or giant cell-containing lesions $[23,24]$. Histiocytes and giant cells in a tissue are in monocyte-macrophage lineage. Macrophages play a central role in the host response to injury and infection, and their energy is predominantly supplied by means of intracellular glucose metabolism $[25,26]$. High uptake of ${ }^{18} \mathrm{~F}-\mathrm{FDG}$ in inflammatory lesions found in this study was consistent with previous studies [27-29]. Although it is still controversial whether histiocytes and giant cells in primary bone tumors are reactive or neoplastic, these cells might partially contribute to the high uptake of ${ }^{18} \mathrm{~F}-\mathrm{FDG}$ in the benign bone and soft tissue lesions [30]. It may be reasonable to consider that high uptake of ${ }^{11} \mathrm{C}$-choline in reactive or neoplastic cells of histiocytes and giant cells is due to the high ${ }^{11} \mathrm{C}$-choline utilization by these cell membranes. Further investigation is necessary to verify this point. The overlap of SUVs was also observed in ${ }^{18} \mathrm{~F}$-FAMT PET. High ${ }^{18} \mathrm{~F}$ FAMT uptake (SUV > 1.0) was found in 1 of 3 giant cell tumors, 2 of 4 desmoid tumors, 1 xanthofibroma, 1 fibroma, 1 neurofibroma, 1 lymphangioma, and 1 aseptic necrosis. This may also be explained from the above reasons.

The differentiation of malignant from benign lesions is crucial to preoperative planning for treatment of musculoskeletal tumors. This study in the current patient population showed that the sensitivity of ${ }^{11} \mathrm{C}$-choline PET was higher than that of ${ }^{18} \mathrm{~F}-\mathrm{FDG}$ PET in musculoskeletal tumors. This is consistent with our previous study [31], which could be explained as follows. A high uptake of ${ }^{18} \mathrm{~F}-\mathrm{FDG}$ in tumors is accomplished only if the tumor metabolism is biased toward excessive glycolysis by activation of the glucose transporter and hexokinase [32]. This may occur, although there seemed to be rare exceptions, if the tumor size is large and the tumor environment is hypoxic because of insufficient blood (oxygen) supply. In contrast, the uptake of ${ }^{11} \mathrm{C}$-choline in tumors is the result of cell membrane synthesis. When ${ }^{11} \mathrm{C}$-choline is incorporated in tumors, it is rapidly phosphorylated (yielding ${ }^{11} \mathrm{C}$-phosphorylcholine) and chemically trapped inside the cell membranes. ${ }^{11} \mathrm{C}$-phosphorylcholine may be the major chemical derived from ${ }^{11} \mathrm{C}$-choline at the time of PET scanning. Thereafter, it is further metabolized and converted to ${ }^{11} \mathrm{C}$-phosphatidylcholine and then integrated in tumor cell membrane [33]. This is the only metabolic pathway known for choline in tumors, although there are other metabolic pathway in other normal organs. Thus, it could be assumed that the ${ }^{11} \mathrm{C}$-choline uptake in tumors is proportional to the tumor cell proliferation rate [15]. When the cut-off value was set at 1.26 , the sensitivity of ${ }^{18} \mathrm{~F}$-FAMT PET for correctly diagnosing malignancy was $66.7 \%$ with a specificity of $85.7 \%$, resulting in an accuracy of $78.8 \%$. The sensitivity of ${ }^{18}$ F-FAMT PET was lower than that of ${ }^{18} \mathrm{~F}$-FDG and ${ }^{11} \mathrm{C}$-choline, whereas it is noteworthy that the specificity was clearly higher than that of ${ }^{18} \mathrm{~F}-\mathrm{FDG}$ and ${ }^{11} \mathrm{C}$-choline.

In this study, we did not evaluate the ability of the agents in grading of malignancy, due to the small histopathological types and tumor grades. Almost all the tumors were in Grade 3. It should be noted that almost all (12/13) the malignant musculoskeletal tumors were correctly diagnosed by ${ }^{11} \mathrm{C}$-choline PET using a cutoff of 2.6 of SUV. It is recommended that ${ }^{11} \mathrm{C}$-choline PET might be used as a screening method for malignant musculoskeletal tumors. Watanabe et al. reported [16], in a 75 musculoskeletal tumors patients study, that ${ }^{18} \mathrm{~F}$-FAMT appeared to be inferior to ${ }^{18} \mathrm{~F}$ FDG with regard to malignancy grading, and the latter tracer consequently may be more useful for noninvasive grading in the surgical staging of musculoskeletal sarcoma. Use of ${ }^{18}$ F-FAMT PET in combination with ${ }^{18} \mathrm{~F}$-FDG PET might be a useful approach for preoperative planning in patients with musculoskeletal tumors. Due to the differences in the accumulation mechanisms of the 3 imaging agents and the difference in patient selection, larger patient populations might be considered to determine which agent is more useful for evaluating the histological grade of musculoskeletal tumors.

\section{Conclusion}

Our findings indicate that ${ }^{11} \mathrm{C}$-choline, ${ }^{18} \mathrm{~F}$-FDG, and ${ }^{18} \mathrm{~F}$ FAMT are useful agents for the evaluation of musculoskeletal tumors. In particular, ${ }^{11} \mathrm{C}$-choline may be superior to the ${ }^{18} \mathrm{~F}$ FDG and ${ }^{18} \mathrm{~F}$-FAMT in detection of musculoskeletal tumors and, thus, may be important for preoperative planning. The use of ${ }^{18} \mathrm{~F}$-FAMT PET in combination with ${ }^{18} \mathrm{~F}$-FDG or ${ }^{11} \mathrm{C}$ choline PET might be a useful approach for preoperative planning in patients with musculoskeletal tumors. The high uptake of ${ }^{18} \mathrm{~F}$-FDG and ${ }^{11} \mathrm{C}$-choline in some benign musculoskeletal tumors and tumor-like lesions, especially histiocytic and giant cell-containing lesions, should be aware of in clinical practice.

\section{Acknowledgments}

This study was partially supported by grants from the Ministry of Education, Culture, sports, science and Technology of the Japanese Government. Dr. H. Zhang was supported by a key project Grant (2006DFB32940) and by the National Basic Research Program (2011CB504400) from the Ministry of Science and Technology of China.

\section{References}

[1] H. Jadvar, S. Gamie, L. Ramanna, and P. S. Conti, "Musculoskeletal system," Seminars in Nuclear Medicine, vol. 34, no. 4, pp. 254-261, 2004.

[2] K. L. Verstraete, H. J. VanderWoude, P. C. Hogendoorn, Y. DeDeene, M. Kunnen, and J. L. Bloem, "Dynamic contrastenhanced MR imaging of musculoskeletal tumors: basic principles and clinical applications," Journal of Magnetic Resonance Imaging, vol. 5, pp. 311-321, 1996.

[3] H. Zhang, K. Yoshikawa, K. Tamura et al., " ${ }^{11} \mathrm{C}-\mathrm{methionine}$ positron emission tomography and survival in patients with bone and soft tissue sarcomas treated by carbon ion radiotherapy," Clinical Cancer Research, vol. 10, no. 5, pp. 1764-1772, 2004.

[4] M. Tian, H. Zhang, N. Oriuchi, T. Higuchi, and K. Endo, "Comparison of ${ }^{11} \mathrm{C}$-choline PET and FDG PET for the differential diagnosis of malignant tumors," European Journal 
of Nuclear Medicine and Molecular Imaging, vol. 31, no. 8, pp. 1064-1072, 2004.

[5] M. Tian, H. Zhang, Y. Nakasone, K. Mogi, and K. Endo, "Expression of Glut-1 and Glut-3 in untreated oral squamous cell carcinoma compared with FDG accumulation in a PET study," European Journal of Nuclear Medicine and Molecular Imaging, vol. 31, no. 1, pp. 5-12, 2004.

[6] O. E. Nieweg, J. Pruim, R. J. van Ginkel et al., "Fluorine18-fluorodeoxyglucose PET imaging of soft-tissue sarcoma," Journal of Nuclear Medicine, vol. 37, no. 2, pp. 257-261, 1996.

[7] A. C. Kole, O. E. Nieweg, H. J. Hoekstra, J. R. Van Horn, H. S. Koops, and W. Vaalburg, "Fluorine-18-fluorodeoxyglucose assessment of glucose metabolism in bone tumors," Journal of Nuclear Medicine, vol. 39, no. 5, pp. 810-815, 1998.

[8] H. Watanabe, T. Shinozaki, T. Yanagawa et al., "Glucose metabolic analysis of musculoskeletal tumours using fluorine18-FDG PET as an aid to preoperative planning," Journal of Bone and Joint Surgery, vol. 82, no. 5, pp. 760-767, 2000.

[9] P. L. Jager, W. Vaalburg, J. Pruim, E. G. E. De Vries, K. J. Langen, and D. A. Piers, "Radiolabeled amino acids: basic aspects and clinical applications in oncology," Journal of Nuclear Medicine, vol. 42, no. 3, pp. 432-445, 2001.

[10] K. Tomiyoshi, K. Amed, S. Muhammad et al., "Synthesis of isomers of 18F-labelled amino acid radiopharmaceutical: position 2- and 3-L-18F- $\alpha$-methyltyrosine using a separation and purification system," Nuclear Medicine Communications, vol. 18, no. 2, pp. 169-175, 1997.

[11] T. Inoue, K. Tomiyoshi, T. Higuichi et al., "Biodistribution studies on L-3-[Fluorine-18] Fluoro- $\alpha$-methyl tyrosine: a potential tumor-detecting agent," Journal of Nuclear Medicine, vol. 39, no. 4, pp. 663-667, 1998.

[12] R. Kumar, H. Dhanpathi, S. Basu, D. Rubello, S. Fanti, and A. Alavi, "Oncologic PET tracers beyond [(18)F]FDG and the novel quantitative approaches in PET imaging," Quarterly Journal of Nuclear Medicine and Molecular Imaging, vol. 52, no. 1, pp. 50-65, 2008.

[13] T. Hara and M. Yuasa, "Automated synthesis of $\left[{ }^{11} \mathrm{C}\right]$ choline, a positron-emitting tracer for tumor imaging," Applied Radiation and Isotopes, vol. 50, no. 3, pp. 531-533, 1999.

[14] O. Kobori, Y. Kirihara, N. Kosaka, and T. Hara, "Position emission tomography of esophageal carcinoma using (11)Ccholine and (18)F-fluorodeoxyglucose: a novel method of preoperative lymph node staging," Cancer, vol. 86, no. 9, pp. 1638-1648, 1999.

[15] T. Hara, K. Inagaki, N. Kosaka, and T. Morita, "Sensitive detection of mediastinal lymph node metastasis of lung cancer with ${ }^{11} \mathrm{C}$-choline PET," Journal of Nuclear Medicine, vol. 41, no. 9, pp. 1507-1513, 2000.

[16] H. Watanabe, T. Inoue, T. Shinozaki et al., "PET imaging of musculoskeletel tumours with fluorine-18 $\alpha$-methyltyrosine: comparison with fluorine-18 fluorodeoxyglucose PET," European Journal of Nuclear Medicine, vol. 27, no. 10, pp. 1509$1517,2000$.

[17] K. Hamacher, H. H. Coenen, and G. Stocklin, "Efficient stereospecific synthesis of no-carrier-added 2-[18F]-fluoro2-deoxy-D-glucose using aminopolyether supported nucleophilic substitution," Journal of Nuclear Medicine, vol. 27, no. 2, pp. 235-238, 1986.

[18] H. Zhang, T. Inoue, S. Alyafei, M. Tian, N. Oriuchi, and K. Endo, "Tumour detectability in 2-dimensional and 3dimensional positron emission tomography using the SET2400W: a phantom study," Nuclear Medicine Communications, vol. 22, no. 3, pp. 305-314, 2001.
[19] J. Aoki, K. Endo, H. Watanabe et al., "FDG-PET for evaluating musculoskeletal tumors: a review," Journal of Orthopaedic Science, vol. 8, no. 3, pp. 435-441, 2003.

[20] N. Shinoura, M. Nishijima, T. Hara et al., "Brain tumors: detection with C-11 choline PET," Radiology, vol. 202, no. 2, pp. 497-503, 1997.

[21] T. Hara, N. Kosaka, and H. Kishi, "PET imaging of prostate cancer using carbon-11-choline," Journal of Nuclear Medicine, vol. 39, no. 6, pp. 990-995, 1998.

[22] T. Inoue, T. Shibasaki, N. Oriuchi et al., "F-18 $\alpha$-methyl tyrosine PET studies in patients with brain tumors," Journal of Nuclear Medicine, vol. 40, no. 3, pp. 399-405, 1999.

[23] J. Johnston, "Giant cell tumor of bone. The role of the giant cell in orthopedic pathology," Orthopedic Clinics of North America, vol. 8, no. 4, pp. 751-770, 1977.

[24] L. Ling, M. J. Klein, H. A. Sissons, G. C. Steiner, and R. J. Winchester, "Expression of Ia and monocyte-macrophage lineage antigens in giant cell tumor of bone and related lesions," Archives of Pathology and Laboratory Medicine, vol. 112, no. 1, pp. 65-69, 1988.

[25] K. Mészáros, G. J. Bagby, and J. J. Spitzer, "Contribution of different organs to increased glucose consumption after endotoxin administration," The Journal of Biological Chemistry, vol. 262, no. 23, pp. 10965-10970, 1987.

[26] R. L. Gamelli, H. Liu, L. K. He, and C. A. Hofmann, "Augmentations of glucose uptake and glucose transporter- 1 in macrophages following thermal injury and sepsis in mice," Journal of Leukocyte Biology, vol. 59, no. 5, pp. 639-647, 1996.

[27] A. Guhlmann, D. Brecht-Krauss, G. Suger et al., "Chronic osteomyelitis: detection with FDG PET and correlation with histopathologic findings," Radiology, vol. 206, no. 3, pp. 749754, 1998.

[28] W. E. Palmer, D. I. Rosenthal, O. I. Schoenberg et al., "Quantification of inflammation in the wrist with gadoliniumenhanced MR imaging and pet with 2-[F-18]-fluoro-2-deoxyD-glucose," Radiology, vol. 196, no. 3, pp. 647-655, 1995.

[29] L. H. Brudin, S. O. Valind, C. G. Rhodes et al., "Fluorine-18 deoxyglucose uptake in sarcoidosis measured with positron emission tomography," European Journal of Nuclear Medicine, vol. 21, no. 4, pp. 297-305, 1994.

[30] J. Aoki, H. Watanabe, T. Shinozaki et al., "FDG PET of primary benign and malignant bone tumors: standardized uptake value in 52 lesions," Radiology, vol. 219, no. 3, pp. 774-777, 2001.

[31] H. Zhang, M. Tian, N. Oriuchi et al., " ${ }^{11}$ C-choline PET for the detection of bone and soft tissue tumours in comparison with FDG PET," Nuclear Medicine Communications, vol. 24, no. 3, pp. 273-279, 2003.

[32] A. C. Clavo, R. S. Brown, and R. L. Wahl, "Fluorodeoxyglucose uptake in human cancer cell lines is increased by hypoxia," Journal of Nuclear Medicine, vol. 36, no. 9, pp. 1625-1632, 1995.

[33] R. Katz-Brull and H. Degani, "Kinetics of choline transport and phosphorylation in human breast cancer cells; NMR application of the zero trans method," Anticancer Research, vol. 16, no. 3, pp. 1375-1380, 1996. 


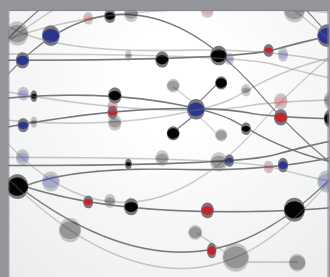

The Scientific World Journal
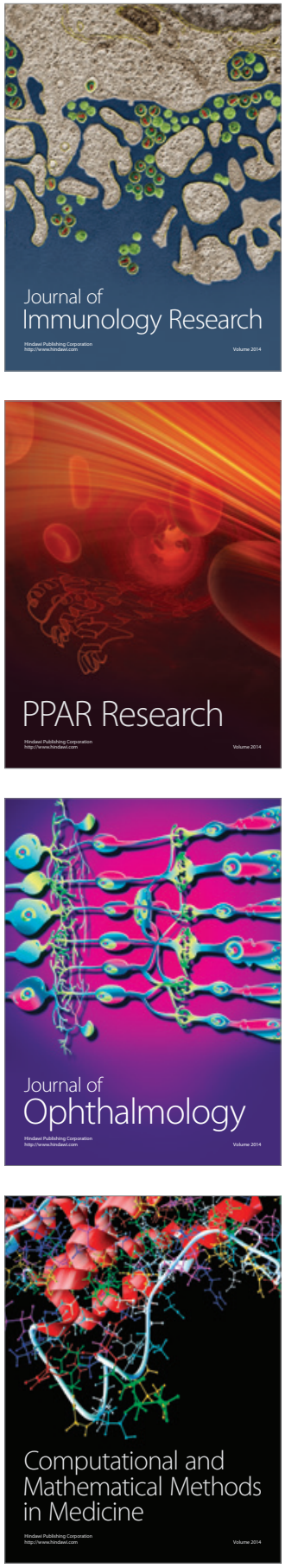

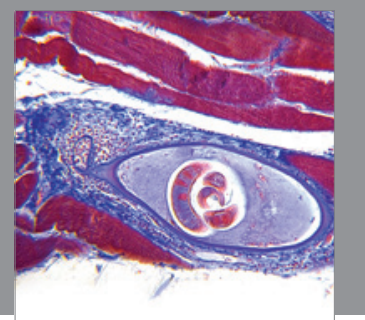

Gastroenterology

Research and Practice
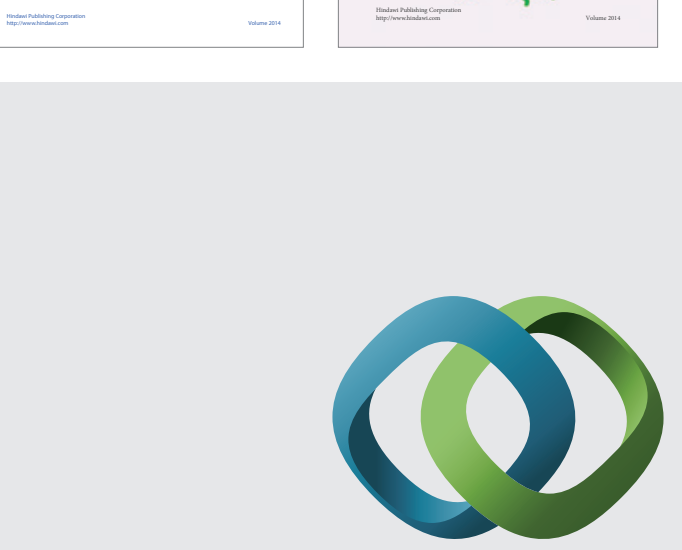

\section{Hindawi}

Submit your manuscripts at

http://www.hindawi.com
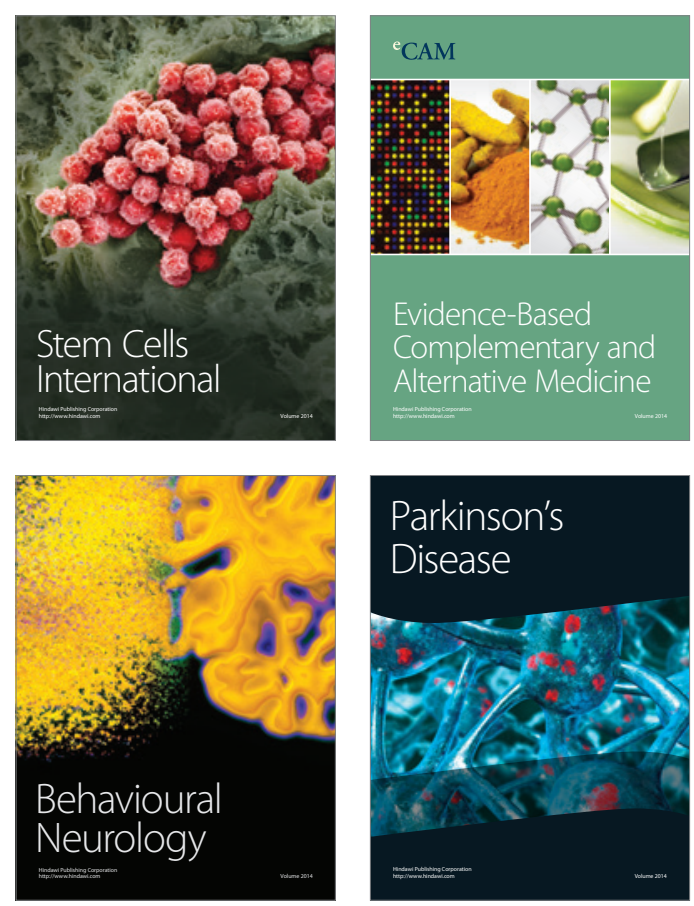

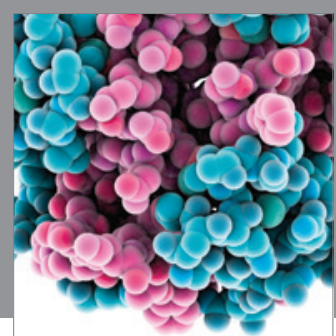

Journal of
Diabetes Research

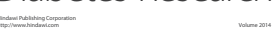

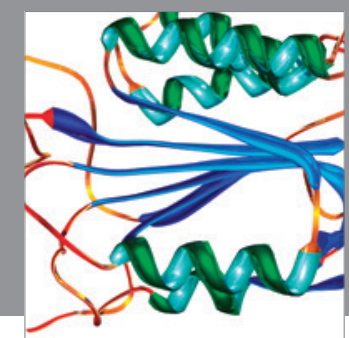

Disease Markers
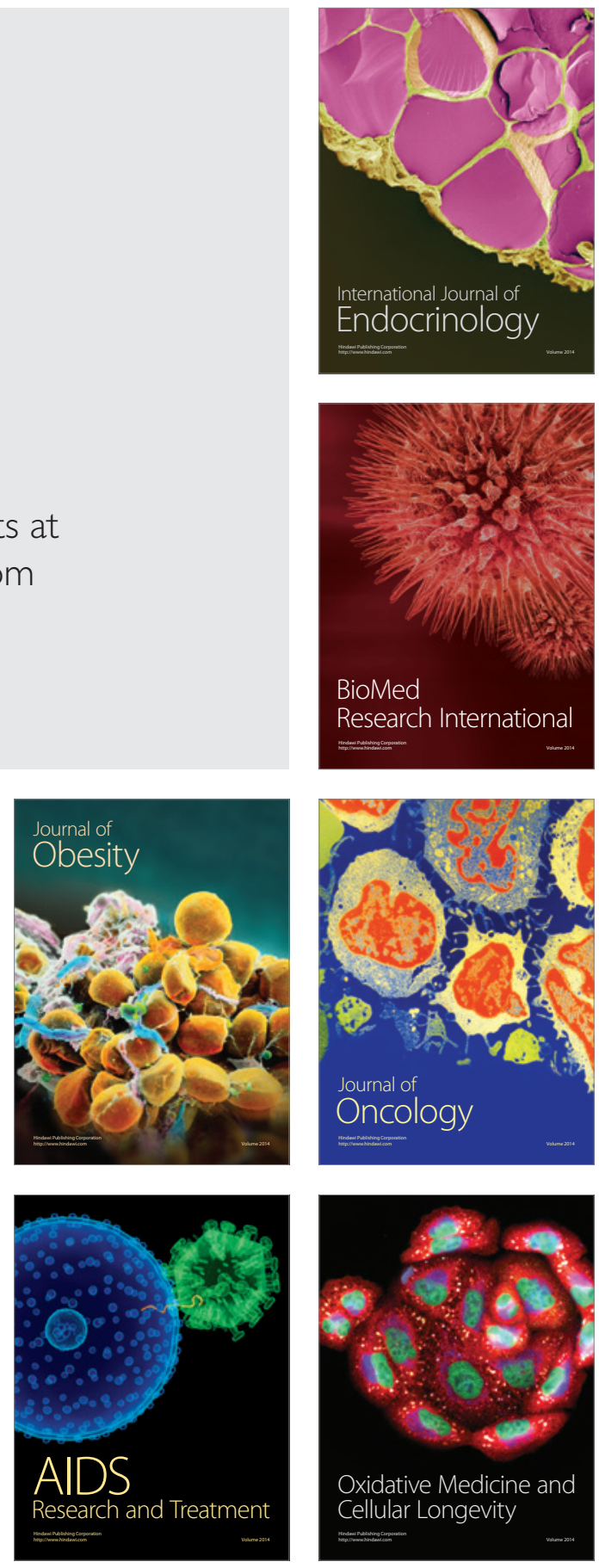